\title{
PERILAKU MEKANIK BATA RINGAN DENGAN PENAMBAHAN SILICA FUME
}

\author{
YON SUBAGIONO ${ }^{1}$, HARNEDI MAIZIR $^{2}$, RENI SURYANITA $^{1^{*}}$
}

${ }^{1}$ Jurusan Teknik Sipil, Universitas Riau, Pekanbaru, Riau

${ }^{2} J u r u s a n$ Teknik Sipil, Sekolah Tinggi Teknologi Pekanbaru, Pekanbaru, Riau

*Corresponding Author : $₫$ reni.suryanita@eng.unri.ac.id

Naskah diterima : 21 Oktober 2020. Disetujui: 19 Januari 2021.

\begin{abstract}
ABSTRAK
Bata beton ringan memiliki keuntungan praktis dan ekonomis dalam pelaksanaan kontruksi sehingga permintaan pasar untuk bata ringan semakin meningkat selama beberapa tahun terakhir. Selain itu pemakaian bata beton konvensional sebagai bahan bagunan non-struktural dinilai masih cukup besar massa jenisnya sehingga memberikan beban lebih ke struktur bangunan. Untuk itu diperlukan bata beton yang memiliki bobot yang lebih ringan sehingga dapat meningkatkan efisiensi baik bahan dan beban yang ditahan struktur maupun pondasi dari bangunan. Penggunaan bata ringan pada umumnya sebagai non struktur berupa dinding panel dan pelat atap. Salah satu cara untuk mengurangi kepadatan bata beton ringan adalah dengan menambahkan pori-pori udara dalam campuran pasta semen atau mortar. Penambahan pori-pori udara dilakukan dengan penambahan foaming agent. Dalam perkembangan teknologi bahan bata ringan perlu ditingkatkan lagi efisiensi dari segi penggunaan bahan dan kualitas bata ringan itu sendiri. Penelitian ini bertujuan untuk menganalisis komposisi campuran yang optimal pada bata ringan tipe Cellular Lightweight Concrete dengan penambahan silica fume. Benda uji dibuat dalam ukuran $10 \mathrm{~cm} \times 20 \mathrm{~cm} \times 60 \mathrm{~cm}$ dengan memvariasikan komposisi silica fume dalam 5 komposisi yaitu $0 \%, 5 \%, 10 \% 15 \%$ dan $20 \%$ dari berat semen yang digunakan dalam campuran bahan. Selanjutnya dilakukan perawatan bata ringan pada umur 3 hari, 7 hari, 14 hari, 21 hari dan 28 hari. Pengujian mekanik yang dilakukan adalah pengujian kuat tekan secara merata pada bagian atas bata ringan. Instrumen pengukuran yang digunakan pada penelitian adalah load cell sebagai pengukur beban dan Linear Variable Differential Transformer (LVDT) untuk mengukur penurunan (displacement) yang terjadi pada permukaan yang dibebani. Data keluaran yang dapat diperoleh dari pengujian ini adalah kuat tekan, modulus elastisitas dan displacement. Nilai kuat tekan bata ringan pada umur 28 hari untuk komposisi 1 sebesar 0,47 MPa, komposisi 2 sebesar 0,82 MPa, komposisi 3 sebesar 0,87 MPa, komposisi 4 sebesar 0,70 MPa, dan komposisi 5 sebesar 0,61 MPa. Berdasarkan hasil penelitian dapat disimpulkan bahwa komposisi bahan campuran yang menggunakan bahan tambah silica fume dengan persentase $10 \%$ dari berat semen menghasilkan kuat tekan yang paling tinggi dengan penurunan permukaan sebesar $3.5 \mathrm{~mm}$ saat dibebani dan modulus elastisitas $527.62 \mathrm{~kg} / \mathrm{m}^{3}$. Diharapkan hasil penelitian ini dapat dijadikan bahan referensi dalam industri dan penelitian bata ringan dengan bahan tambah silica fume untuk mendapatkan sifat mekanik yang optimal pada bata ringan.
\end{abstract}

Kata kunci : Bata ringan, displacement, kuat tekan, modulus elastisitas, silica fume 


\section{PENDAHULUAN}

Beton merupakan jenis material konstruksi yang paling banyak digunakan dalam pembangunan saat ini. Penggunaan beton sebagai material konstruksi struktural dan non struktural mempunyai keunggulan yaitu mudah dalam pengerjaannya, mudah dibentuk, lebih ekonomis, dan tahan terhadap panas. Akan tetapi dalam penggunaan non-struktural, bata beton konvensional dinilai cukup besar massa jenisnya. Penggunaan beton ringan merupakan alternatif dalam mengurangi beban struktur. Berdasarkan (SNI 03-2847, 2019), beton ringan adalah beton pada unsur material nya menggunakan agregat ringan dengan berat jenis beton tidak lebih dari $1840 \mathrm{~kg} / \mathrm{m}^{3}$. Sebagai komponen non struktural diperlukan bata beton yang memiliki bobot yang lebih ringan sehingga dapat meningkatkan efisiensi baik bahan, beban yang ditahan struktur maupun pondasi dari bangunan. Berat jenis bata ringan yang berkisar $400-600 \mathrm{~kg} / \mathrm{m}^{3}$ dikategorikan sebagai bata dengan kepadatan rendah dan digunakan untuk bahan isolasi pengganti glasswool dan woodwool. Bata ringan dengan berat $800-1000 \mathrm{~kg} / \mathrm{m}^{3}$ dikategorikan bata ringan dengan kepadatan sedang sering digunakan untuk pembuatan precast blocks dengan ukuran 600x200x100 mm yang digunakan sebagai dinding menggantikan jenis bata konvensional. Sedangkan bata ringan dengan berat $1200-1800 \mathrm{~kg} / \mathrm{m}^{3}$ dikategorikan bata dengan kepadatan tinggi. Semakin hari permintaan bata ringan di pasaran semakin meningkat. Contoh penggunaan bata ringan sebagai dinding bangunan dapat dilihat pada Gambar. 1.

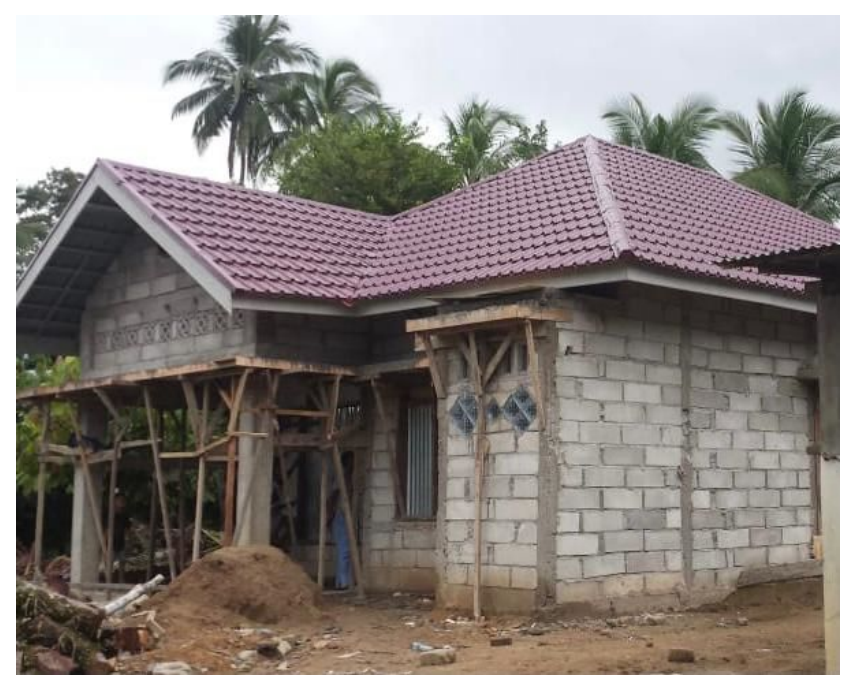

Gambar 1. Penggunaan bata ringan sebagai dinding pada bangunan rumah tinggal

Cellular Lightweigth Concrete (CLC) adalah jenis bata ringan, dimana dalam proses pembuatannya agregat kasar (kerikil) digantikan dengan foaming agen. Penggunaan foaming agen untuk menghasilkan busa (foam) dimana dalam proses pencampuran busa organik ini tidak terjadi proses kimiawi. Untuk mengoptimalkan kualitas dari bata ringan diperlukan bahan tambah sehingga dapat meningkatkan kuat tekan dan modulus elastisitas dari bata ringan tersebut. Salah satu bahan tambah yang digunakan dalam penelitian ini adalah silica fume. Silica fume merupakan material pozzolanic terbentuk dari hasil tanur tinggi yang merupakan produk sampingan logam silicon. Silica fume berwarna abu-abu dan berbentuk serbuk halus dengan diameter berkisar antara 0,1-1,0 micron meter. (ASTM C1240, 2019).

Tabel berikut menjelaskan hasil kesimpulan peneliti terdahulu dalam penggunaan silica fume dan bahan pozolan lain untuk beton mutu tinggi dan beton ringan. 
Tabel 1. Penelitian terdahulu penggunaan silica fume

\begin{tabular}{|c|c|c|c|}
\hline No. & Peneliti & Komposisi Penelitian & Kesimpulan \\
\hline 1. & Febrianto (2016) & $\begin{array}{l}\text { Penambahan silica fume } \\
\text { sebesar } 20 \%, 30 \%, 40 \% \text { dan } \\
50 \% \text { pada campuran porous } \\
\text { concrete block }\end{array}$ & 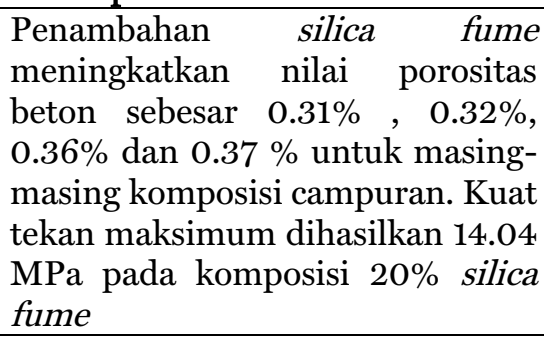 \\
\hline 2. & $\begin{array}{l}\text { Budiawati et al } \\
(2018)\end{array}$ & $\begin{array}{l}\text { Penggunaan silica fume } \\
\text { sebesar } 7 \% \text { pada campuran } \\
\text { beton dengan recycled } \\
\text { coarse aggregate (RCA) }\end{array}$ & $\begin{array}{l}\text { Penambahan silica fume } 7 \% \text { pada } \\
\text { beton porous meningkatkan daya } \\
\text { tahan beton porous terhadap } \\
\text { abrasi. }\end{array}$ \\
\hline 3. & $\begin{array}{lll}\text { Fajrin } & \text { et. } & \text { Al. } \\
(2016) & & \end{array}$ & $\begin{array}{l}\text { Penggunaan silica fume } \\
\text { sebesar } 3 \% \text { pada campuran } \\
\text { mortar. }\end{array}$ & $\begin{array}{l}\text { Penambahan silica fume } 3 \% \\
\text { menyebabkan penurunan daya } \\
\text { serap mortar terhadap air sebesar } \\
18,34 \% \text {, dan meningkatkan kuat } \\
\text { tekan mortar. }\end{array}$ \\
\hline 4. & Susilo (2019) & $\begin{array}{l}\text { Penambahan silica fume } \\
\text { sebesar } 3 \%, 6 \%, 9 \%, 12 \% \\
\text { dan } 15 \% \text { pada campuran } \\
\text { beton ringan. }\end{array}$ & $\begin{array}{l}\text { Kuat tekan optimum beton ringan } \\
\text { diperoleh pada komposisi } \\
\text { penambahan silica fume } 9 \% \\
\text { dengan nilai kuat tekan sebesar } \\
21.20 \mathrm{MPa} \text {. }\end{array}$ \\
\hline 5. & Tarru (2017) & $\begin{array}{l}\text { Penggunaan silica fume } \\
\text { sebesar } 5 \%, 10 \% \text { dan } 15 \% \\
\text { sebagai campuran filler } \\
\text { beton }\end{array}$ & $\begin{array}{l}\text { Hasil penelitian umur beton } 28 \\
\text { hari dengan penambahan silica } \\
\text { fume sebesar } 5 \%, 10 \% \text { dan } 15 \% \\
\text { adalah } 37.10 \mathrm{MPa}, 40,39 \mathrm{MPa} \text { dan } \\
43,62 \mathrm{MPa}\end{array}$ \\
\hline
\end{tabular}

Kekuatan bata ringan berbeda dengan kekuatan beton ringan. Pada umumnya bata ringan memiliki kekuatan rendah berkisar 0.5 hingga 2.0 MPa. Tim peneliti terdahulu (Maizir et al., 2019) telah melakukan pengujian bata ringan dengan komposisi campuran semen dan pasir rasio 2:3 menghasilkan kekuatan 0.68 MPa. Sedangkan peneliti lainnya (Bella et al., 2017) mendapatkan hasil kuat tekan bata ringan dengan campuran $40 \%$ fly ash sebesar $0,633 \mathrm{MPa}$.

Penggunaan bata beton dengan kepadatan rendah, secara signifikan mengurangi bobot sendiri struktur beton sehingga memungkinkan pengurangan kolom dan ukuran pondasi dan beban lainnya serta pengurangan dalam hal biaya. Keuntungan lain dari beton ringan termasuk sifat insulasi panas yang baik, ketahanan api yang lebih baik. Salah satu cara untuk mengurangi kepadatan beton tersebut adalah dengan menambahkan pori-pori udara dalam campuran pasta semen atau mortar. Penambahan pori-pori udara dilakukan dengan penambahan foaming agent. Dalam perkembangan teknologi bahan bata ringan perlu ditingkatkan lagi efisiensi dari segi penggunaan bahan dan kualitas bata ringan itu sendiri, antara lain dengan mengganti sebahagian semen dengan silica fume. Dalam penelitian ini mengkaji persentase penambahan silica fume yang optimal sebagai pengganti semen untuk mendapatkan nilai kuat tekan, modulus elastisitas dan penurunan (displacement) permukaan bata ringan pada saat dibebani.

Penelitian ini bertujuan untuk mendapatkan komposisi campuran optimum bata ringan CLC dengan penambahan silica fume dan mengurangi penggunaan semen pada campuran. Dengan demikian diharapkan penelitian ini dapat menghasilkan bata ringan yang lebih berkualitas dan hasil penelitian dapat sebagai rujukan bagi penelitan selanjutnya. 


\subsection{Jenis bata ringan}

Jenis bata ringan yang umum dikenal dibedakan menjadi 2 yaitu Autoclaved Aerated concrete (AAC) dan Cellular Lightweight Concrete (CLC). Perbedaan bata ringan AAC dengan CLC dari segi proses produksi bata ringan AAC merupakan beton selular dalam proses pembentukan terjadi gelembung udara disebabkan oleh reaksi kimia yang meyembabkan aluminium pasta mengembang. Material pembuatan material bata rigan AAC adalah pasir silika yang harus digiling sampai ukuran mikro, dimana proses pengeringan pada bata ringan AAC harus menggunakan tabung bertekanan tinggi ( tabung autoklaf) sedangkan pada bata ringan CLC proses pembentukan gelembung udara terpisah satu sama lain dan proses pengeringan atau curing bata ringan CLC dilakukan secara alami. Dalam proses pengerjaan CLC menggunakan foaming agent yang menghasilakan busa organik yang sangat stabil dan ketika proses pencampuran adonan tidak terjadi reaksi kimia (Bella et al., 2017).

Berat Jenis bata ringan CLC umumnya memiliki kepadatan yang lebih rendah dari batu bata lainnya dimana bahan baku bata ringan terdiri dari pasir silika, semen, air, ditambah bahan pengembang yang diolah dengan tekanan uap air. Berat bata ringan ini bisa diatur sesuai kebutuhan, dimana massa jenis bata ringan berkisar antara 400 hingga $1.800 \mathrm{~kg} / \mathrm{m}^{3}$ (Efendi et al., 2019). Bobot yang ringan menjadi salah satu keunggulan bata ringan yang berdampak signifikan bila digunakan pada proyek gedung bertingkat dan pada daerah yang mempunyai kondisi tanah lunak karena akan mengurangi beban yang dibebankan pada pondasi (Oktavianita et al 2018).

Bata ringan dapat dibuat dengan tiga cara yaitu :

a. Pembuatan bata ringan dengan pemakaian agregat ringan, misalnya agregat kasar yang ringan, agregat halus yang ringan atau keduanya,

b. Pembuatan bata ringan dengan menggunakan foaming agent yang menghasilkan busa yang membentuk gelembung-gelembung udara pada bata ringan.

c. Pembuatan bata ringan dapat juga dilakukan tanpa menggunakan pasir atau disebut bata non pasir, mengakibatkan terjadinya rongga pada agregat kasar..

Dalam proses produksi bata ringan CLC dapat dilakukan dengan menggunakan peralatan dan pabrikasi standar sehingga dapat dilakukan dan di integrasikan dengan pabrikasi beton konvensional. Beberapa kelebihan bata ringan CLC antara lain struktur kedap suara dan kedap air sehingga tidak mudah terjadi rembesan air, mudah dipotong saat aplikasi, tidak memerlukan plasteran yang tebal dan memiliki bentuk dan ukuran serta kualitas yan seragam. Gambar 2 menunjukkan bentuk bata ringan CLC. 


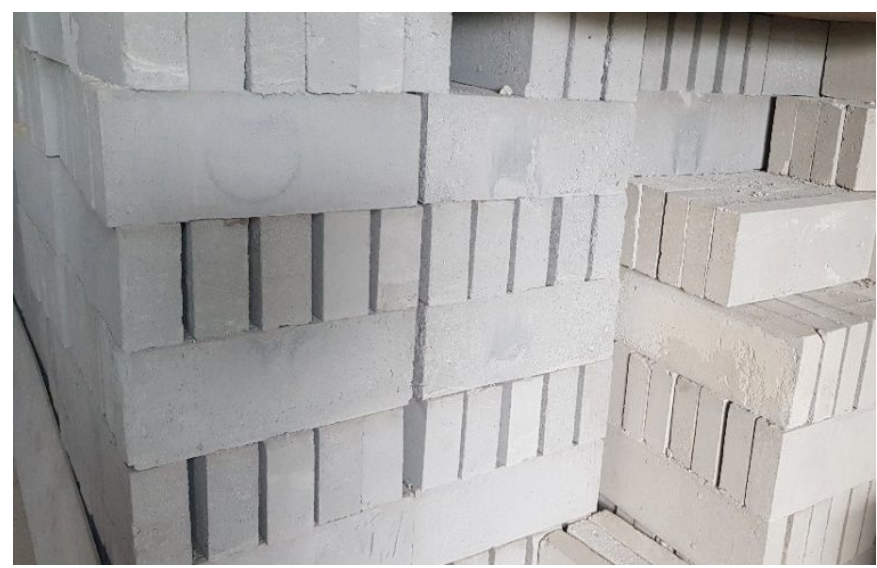

Gambar 2. Bata Ringan CLC (Cellular Lightweight Concrete)

Sebagai bahan tambah penggunaan silica fume dilakukan dengan memberikan presentase yang cukup kecil, baik sebagai bahan tambah maupun sebagai bahan pengganti semen. Pengawasan dan ketelitian yang ketat diperlukan agar memperoleh prosentase yang sesuai dan tidak berlebihan yang dapat mengakibatkan penurunan kualitas dan kinerja bata beton ringan.

Bahan tambah (admixture) terdiri dari 2 (dua) jenis, yaitu bahan tambah yang mempunya sifat kimiawi (chemical Admixture) dan bahan tambah yang bersifat mineral (additive). Bahan tambah (admixture) berdasarkan ACI (American Concrete Institute) merupakan bahan yang ditambahkan pada campuran beton selain air, agregat dan semen hidrolis. Penambahan bahan tambah tersebut tidak akan merubah komposisi yang signifikan pada campuran beton karena bahan tambah tersebut bertujuan untuk merubah dan memperbaiki sifat dan karasteritik beton.

Berdasarkan tujuan penggunaan bahan tambah kimia (chemical admixture) antara lain :

a. Water Reducer merupakan bahan tambah kimia untuk mengurangi penggunaan air pada proses pencampuran beton

b. Retarder merupakan bahan tambah kimia pada beton untuk memperlambat proses ikatan pada beton

c. Accelerator merupakan bahan tambah kimia yang digunakan untuk mempercepat ikatan dan pengerasan pada beton.

d. Water Reducer \& Retarder merupakan bahan tambah yang mempunyai fungsi ganda untuk mengurangi penggunaan air dan memperlambat proses pengikatan pada beton

e. Water Reducer \& Accelerator merupakan bahan tambah yang mempunyai fungsi ganda untuk mengurangi penggunaan air dan mempercept proses pengerasan pada beton

f. Superplasticizer (Water Reducer \& High Range) merupakan bahan tambah yang berfungsi sebagai pengencer campuran dengan faktor air semen tetap.

g. Water Reducer \& High Range \& Retarder bahan tambah mempunyai fungsi ganda untuk mengurangi penggunaan air dengan faktor air semen tetap dan dapat memperlambat proses pengerasan dan ikatan pada beton.

Mineral (additive admixture) merupakan bahan tambah yang dimaksudkan untuk memperbaiki kinerja beton dan biasanya dapat digunakan untuk menggantikan sebagian bahan semen, Bahan tambah mineral antara lain seperti pozzolan, fly ash, slag, dan silica fume. Silica fume merupakan material pozzolanic terbentuk dari hasil tanur tinggi yang merupakan produk sampingan logam silicon dari reduksi kuarsa dengan kemurnian tinggi. 
Silica fume memiliki kandungan silikon dioksida amorf (senyawa silikat) yang sangat tinggi yaitu kandungan $\mathrm{SiO}_{2}$ sebesar 87\% hingga $97 \%$ (ACI Committee 234, 2006). Silica fume mempunyai warna abu-abu dan berbentuk serbuk yang sangat halus dengan diameter berkisar antara 0,1-1,0 micron meter (ASTM C1240, 2019).

Penggunaan silica fume sebagai bahan tambah pada pencampuran beton membutuhkan perentase air yang lebih banyak, biasanya diatas $5 \%$ dibandingkan dengan campuran beton tanpa silica fume. Penggunaan silica fume dalam campuran beton dapat membuat campuran lebih kohesif sehingga memperkecil resiko terjadi segregasi dan terjadinya bleeding (Sebayang, 2011).

Silica fume sebagai bahan additive mempunyai dua sifat yaitu sifat fisik dan sifat kimia sebagai berikut:

a. Sifat fisik, berwarna abu-abu sampai dengan abu abu gelap, diameter butiran rata-rata 0,1- 1 mikron, dengan specific surface $20000 \mathrm{~m}^{2} / \mathrm{kg}$, (1/100 ukuran partikel semen), berat jenis silica fume 2,2 dan berat volumenya sebesar $200-300 \mathrm{~kg} / \mathrm{m}^{3}$.

b. Sifat kimia, merupakan material pozzolanic terbentuk dari hasil tanur tinggi yang merupakan produk sampingan logam silicon dari reduksi kuarsa dengan kemurnia tinggi. Silica fume memiliki kandungan silikon dioksida amorf (senyawa silikat) yang sangat tinggi yaitu kandungan $\mathrm{SiO}_{2}$ sebesar 87 sampai dengan $97 \%$. Pada campuran beton silica fume digunakan sebagai pengganti sebagian semen atau sebagai bahan tambah (filler), dengan persentase penggunaan silica fume mulai 3\%-30\% dari total berat semen. Pada proses kimianya bahan $\mathrm{SiO} 2$ dalam silica fume akan bereaksi dengan kapur bebas yang dilepaskan semen sehingga terbentuk senyawa kalsium silikat hidrat (CSH) yang menjadi unsur dalam proses pengerasan semen.

Penggunaan silica fume dalam beton mempunyai keunggulan antara lain dapat meningkatkan kuat tekan, kuat tarik, ketahanan pada serangan klorida, abrasi dan korosi, serta nilai modulus elastisitas beton. Selain itu penggunaan silica fume dapat memperkecil rangkak dan susut pada beton, serta koefisien permeabilitas beton menjadi lebih kecil.

\subsection{Kuat tekan \& modulus elastisitas}

Kuat tekan bata ringan merupakan daya tahan bata ringan terhadap gaya tekan persatuan luas, sehingga kuat tekan dapat dihitung menggunakan rumus sebagai berikut :

$$
\begin{array}{ll}
f \mathrm{c}=\frac{P}{A} & \\
\text { dimana } & \\
f \mathrm{c} \quad=\text { Kuat tekan/Tegangan } \\
\mathrm{P} \quad=\text { Gaya tekanan atau beban yang diterima benda uji } \\
\mathrm{A} \quad=\text { Luas bidang tekan }
\end{array}
$$

Modulus elastisitas merupakan nilai yang digunakan untuk mengukur benda uji atau ketahanan bahan untuk mengalami deformasi elastis ketika gaya diterapkan pada benda itu. Nilai modulus elastisitas dapat diukur dengan menggunakan rumus berikut :

$$
\text { Modulus Elastis }=\frac{\text { Tegangan }}{\text { Regangan }}
$$

Nilai regangan merupakan perubahan panjang akibat tekanan dibagi dengan panjang awal, regangan dapat dihitung dengan rumus : 
Regangan $=\frac{\Delta L}{L}$

dimana :

$\triangle \mathrm{L}=$ Perubahan panjang

$\mathrm{L}=$ Panjang awal

\section{METODOLOGI PENELITIAN}

Langkah awal dalam penelitian adalah persiapan bahan yang dibutuhkan dalam membuat bata ringan berupa agregat halus, air, foaming agent dan semen serta bahan tambah silica fume. Benda uji trial mix dibuat dalam ukuran $10 \times 10 \times 10 \mathrm{~cm}$ digunakan untuk presentase campuran bata ringan yang optimal seperti terlihat pada Gambar 3. Setelah diperoleh presentase yang optimal maka dibuat bata ringan dengan ukuran yang sebenarnya yaitu 10 x 20 x $60 \mathrm{~cm}$ terlihat pada Gambar 4.

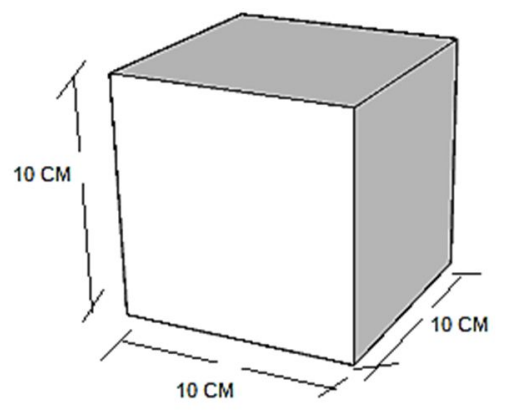

Gambar 3. Bentuk benda uji ukuran 10x10x10 cm

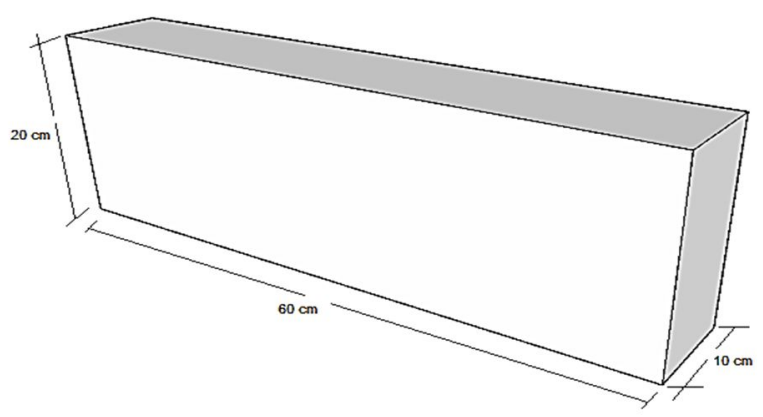

Gambar 4. Bentuk benda uji ukuran 10x20x60 cm

Benda uji dibuat dalam beberapa sampel dengan memvariasikan komposisi silica fume sebagai variabel bebas sebesar $0 \%, 5 \%, 10 \%, 15 \%$ dan $20 \%$. Kemudian dilakukan perawatan/curing selama 3, 7, 14, 21, dan 28 hari. Setelah umur curing tercapai dilakukan pengujian kuat tekan. Komposisi campuran bata ringan dapat dilihat pada Tabel 2 berikut.

Tabel 2. Komposi Campuran Bata Ringan

\begin{tabular}{lllllllll}
\hline No. & Komposisi & $\begin{array}{l}\text { Semen } \\
(\mathrm{Kg})\end{array}$ & $\begin{array}{l}\text { Pasir } \\
(\mathrm{Kg})\end{array}$ & $\begin{array}{l}\text { Air } \\
(\mathrm{Kg})\end{array}$ & $\begin{array}{l}\text { Foam } \\
(\mathrm{Kg})\end{array}$ & Agen & $\begin{array}{l}\text { Silica } \\
(\mathrm{Kg})\end{array}$ & Fume \\
\hline 1 & $\begin{array}{l}\text { Silica fume } \\
\text { (Normal) }\end{array}$ & $0 \%$ & 3 & 4.35 & 1.5 & 0.57 & 0 & \\
\hline 2 & Silica fume 5\% & 2.85 & 4.35 & 1.5 & 0.57 & 0.15 & \\
\hline
\end{tabular}




\begin{tabular}{lllllllll}
\hline No. & Komposisi & $\begin{array}{l}\text { Semen } \\
(\mathrm{Kg})\end{array}$ & $\begin{array}{l}\text { Pasir } \\
(\mathrm{Kg})\end{array}$ & $\begin{array}{l}\text { Air } \\
(\mathrm{Kg})\end{array}$ & $\begin{array}{l}\text { Foam } \\
(\mathrm{Kg})\end{array}$ & Agen & $\begin{array}{l}\text { Silica } \\
(\mathrm{Kg})\end{array}$ & Fume \\
\hline 3 & Silica fume $10 \%$ & 2.70 & 4.35 & 1.5 & 0.57 & 0.30 & \\
\hline 4 & Silica fume $15 \%$ & 2.55 & 4.35 & 1.5 & 0.57 & 0.45 & \\
\hline 5 & Silica fume $20 \%$ & 2.40 & 4.35 & 1.5 & 0.57 & 0.60 & \\
\hline
\end{tabular}

Tahap selanjutnya adalah membuat 3 sampel ukuran 10x20x60 $\mathrm{cm}$ dengan satu variasi mix berdasarkan hasil nilai kuat tekan optimum trial mix. Pengujian sifat mekanik dilakukan setelah masa curing 28 hari, dimulai dengan mempersiapkan alat sesuai setting pengujian dimana sebelum pengujian benda uji di ukur dan ditimbang. Pengujian tekan dilakukan secara merata pada bagian atas balok. Instrumen pengukuran atau alat pengumpul data yang digunakan adalah load cell sebagai pengukur beban dan linear variable differential transformer (LVDT) yang dipasang pada bagian atas balok untuk pengukuran penurunan permukaan. Variabel tergantung yang merupakan data keluaran yang dapat diperoleh dari pengujian ini berupa kuat tekan, modulus elastisitas dan penurunan permukaan. Kuat tekan bata ringan yang direncanakan adalah sebesar $1 \mathrm{MPa}$ dan density rencana adalah sebesar $850 \mathrm{sd} 900 \mathrm{~kg} / \mathrm{m}^{3}$.

\section{HASIL DAN PEMBAHASAN}

Kekuatan bata ringan dipengaruhi oleh beberapa hal yaitu karakteristik dari material pembentuk bata ringan, faktor air semen, cara pengadukan, komposisi campuran, mesin pengadukan yang digunakan, serta perawatan dalam proses pengerasan. Pada penelitian ini bata ringan diuji kuat tekan saat berumur 3, 7, 14, 21 dan 28 hari dari mulai penuangan campuran ke cetakan. Setiap pengujian digunakan 3 buah sampel bata ringan dengan ukuran tinggi $10 \mathrm{~cm}$, lebar $10 \mathrm{~cm}$, dan panjang $10 \mathrm{~cm}$ seperti terlihat pada Gambar 5 .

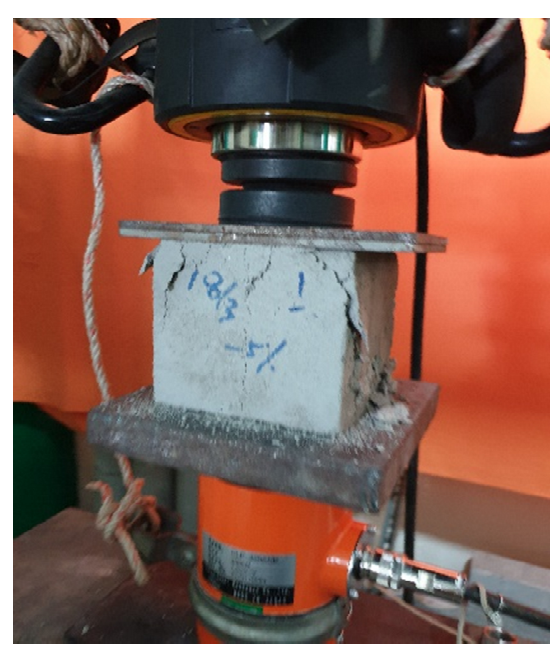

Gambar 5. Pengujian kuat tekan bata ringan

Hasil pengujian sampel berumur 3 hari hingga 28 hari menghasilkan kuat tekan maksimum pada komposisi campuran 10\% silica fume sebesar 0,35 MPa pada usia 3 hari, 0,57 MPa pada usia 7 hari, $0,77 \mathrm{MPa}$ pada usia 14 hari, $0,83 \mathrm{MPa}$ pada usia 21 hari dan $0,87 \mathrm{MPa}$ pada usia 28 hari seperti terlihat pada Gambar 6. 


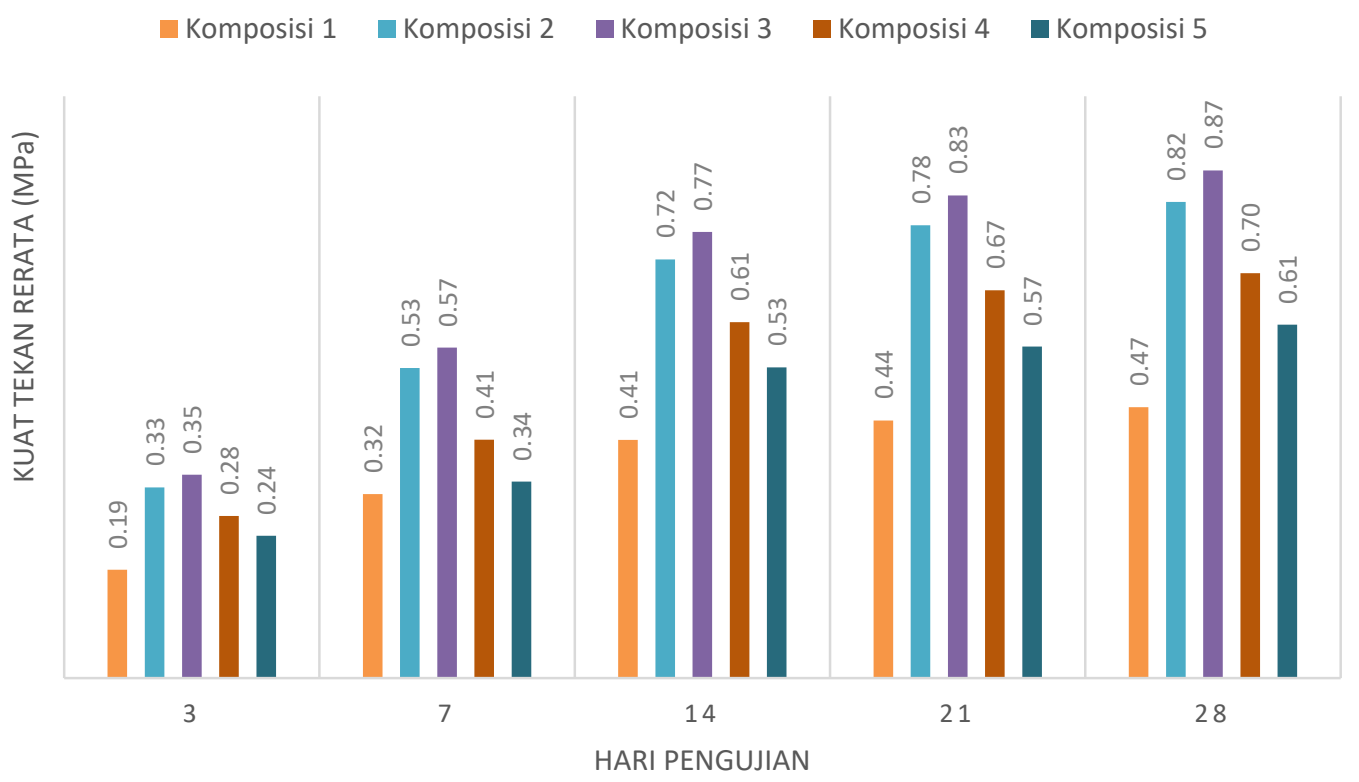

Gambar 6. Hasil pengujian kuat tekan

Berdasarkan pengujian di laboratorium terlihat hasil kuat tekan pada komposisi 4 dan komposisi 5, meskipun memiliki nilai kuat tekan yang lebih tinggi dari komposisi 1 (campuran tanpa silica fume) namun mengalami penurunan nilai kuat tekan dibandingkan dengan komposisi 2 dan komposisi 3. Hasil ini sesuai dengan penelitian terdahulu yang mengatakan penggunaan silica fume yang terlalu banyak dapat menurunkan mutu beton, dikarenakan penyerapan air yang terlalu besar oleh silica fume sehingga air yang dibutuhkan untuk hidrasi tidak cukup dan proses hidrasi menjadi tidak sempurna sehingga mengakibatkan kekuatan beton menjadi rendah. Sehingga komposisi optimal bata ringan dengan campuran bahan tambah silica fume adalah komposisi 3 dengan tambahan silica fume sebanyak $10 \%$.

Berdasarkan hasil kuat tekan maksimal yang dihasilkan dari komposisi campuran optimum pada komposisi 3, maka dibuat banda uji bata ringan skala prototype dengan ukuran 10x20x60 cm. Pengujian benda uji ukuran prototype ini bertujuan untuk memperoleh nilai modulus elastisitas dan penurunan seperti Gambar 7.

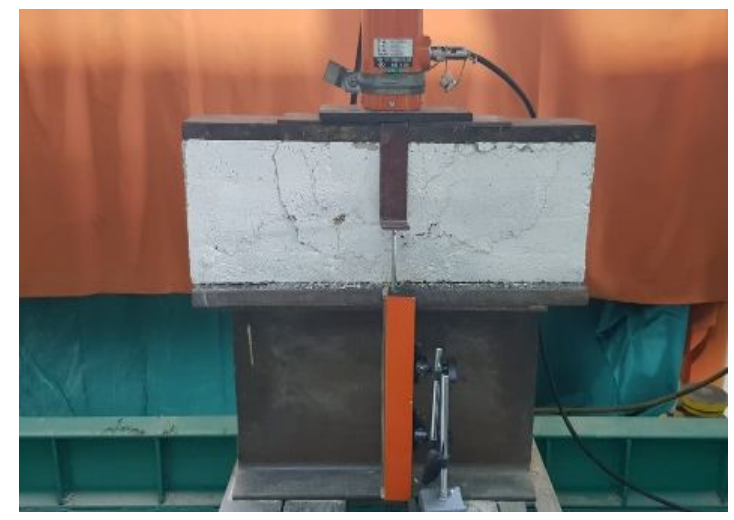

Gambar 7. Pengujian kuat tekan dan penurunan bata ringan 
Pengujian kuat tekan dan penurunan (displacement) bata ringan dengan komposisi campuran $10 \%$ silica fume pada umur curing 28 hari menghasilkan kuat tekan sebesar 0.93 MPa dengan nilai penurunan sebesar $3.5 \mathrm{~mm}$, dimana density campuran benda uji adalah sebesar $857.9 \mathrm{~kg} / \mathrm{m} 3$. Grafik hubungan kuat tekan dan penurunan dapat dilihat pada Gambar 8 berikut.

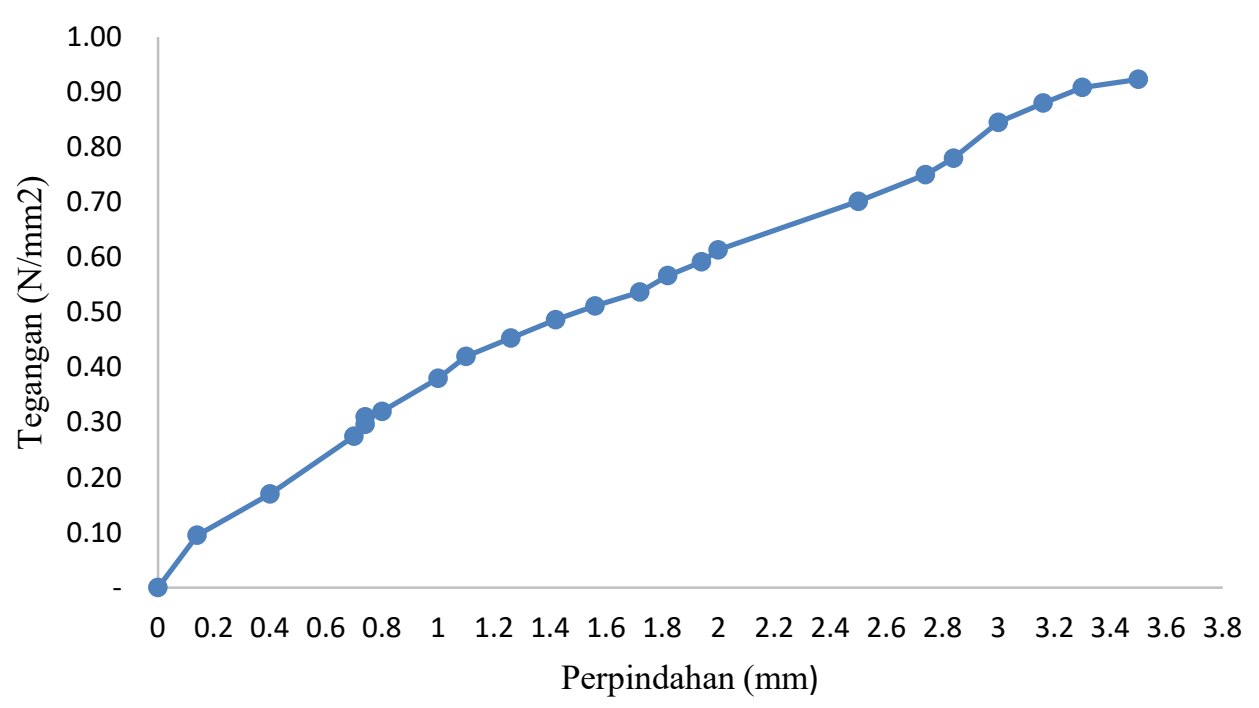

Gambar 8. hubungan kuat tekan dan penurunan

Berdasarkan Gambar 8 terlihat bahwa hubungan antara tegangan dan penurunan (displacement) mendekati garis lurus atau linier dengan hasil kuat tekan $0.92 \mathrm{MPa}$ dengan tetapi masih dibawah kuat tekan yang direncanakan sebesar $1 \mathrm{MPa}$. Sedangkan berdasarkan rumus 2 dan 3 diperoleh nilai modulus elastisitas bata ringan ukuran 10x20x60 cm sebesar $527.62 \mathrm{Kg} / \mathrm{m}^{3}$.

\section{KESIMPULAN DAN SARAN}

Berdasarkan hasil pengujian sifat mekanik kuat tekan bata ringan terhadap 5 variasi komposisi silica fume yang berbeda dengan 3 sampel uji untuk masing-masing komposisi, maka dapat disimpulkan:

a. Pengujian kuat tekan bata ringan umur 28 hari dari komposisi 1 sebesar 0,47 $\mathrm{MPa}$, komposisi 2 sebesar 0,82 MPa, komposisi 3 sebesar 0,87 MPa, komposisi 4 sebesar 0,70 $\mathrm{MPa}$, dan komposisi 5 sebesar 0,61 MPa.

b. Komposisi dengan kenaikan kuat tekan terbesar adalah komposisi 3, dengan nilai kuat tekan pada umur 7, 14, dan 28 hari sebesar 0,57 MPa, 0,77 MPa, dan 0,87 MPa. Pada komposisi 3 digunakan tambahan silica fume sebanyak $10 \%$ dari berat semen. Maka komposisi 3 adalah yang paling optimal untuk komposisi campuran bata ringan dengan tambahan silica fume.

c. Pengaruh bahan tambah silica fume terhadap kuat tekan bata ringan adalah peningkatan kuat tekan yang tinggi. Dibandingkan dengan kuat tekan pada umur 28 hari komposisi 1 yang tidak ditambah silica fume yaitu $0,47 \mathrm{MPa}$, maka komposisi 2 pada umur 28 hari dengan tambahan silica fume $5 \%$ dari berat semen meningkatkan kuat tekan bata ringan sebanyak 0,35 MPa atau 75.88\%. Komposisi 3 pada umur 28 hari 
dengan tambahan silica fume 10\% meningkatkan kuat tekan sebanyak 0,41 MPa atau $87,46 \%$. Komposisi 4 pada umur 28 hari dengan tambahan silica fume $15 \%$ dari berat semen meningkatkan kuat tekan sebanyak 0,23 MPa atau 49,55\%. Serta komposisi 5 pada umur 28 hari dengan tambahan silica fume $20 \%$ dari berat semen meningkatkan kuat tekan sebanyak 0,14 MPa atau 30,51\%.

d. Pengujian kuat tekan bata ringan ukuran 10x20x60 $\mathrm{cm}$ dengan komposisi silica fume $10 \%$ menghasilkan kuat tekan sebesar $0.92 \mathrm{MPa}$ dengan nilai penurunan permukaan $3.5 \mathrm{~mm}$ dan nilai modulus elastisitas $527.62 \mathrm{Kg} / \mathrm{m}^{3}$.

\section{DAFTAR PUSTAKA}

ACI Committee 234. (2006). 234R-06 Guide for the Use of Silica Fume in Concrete. Aci 234R-O6, 96(Reapproved), 0-64.

ASTM C1240. (2019). Adequacy of the ASTM C1240 Specifications for Nanosilica Pozzolans. The Open Civil Engineering Journal, 13(1).

Bella, R. A., Pah, J. J. S., \& Ratu, A. G. (2017). Perbandingan Persentase Penambahan Fly Ash Terhadap Kuat Tekan Bata Ringan Jenis CLC. VI(2), 199-204.

Budiawati, D., Arifi, E., \& Nainggolan, C. R. (2018). Pengaruh Penggunaan Silica Fume dan Fly Ash sebagai Pengganti Semen terhadap Keausan Beton Porous yang Menggunakan RCA (Recycled Coarse Aggregate). Jurnal Mahasiswa Jurusan Teknik Sipil, 1(2), pp-725.

Efendi, M. rizal D., Suryanita, R., \& Maizir, H. (2019). Studi eksperimental sifat mekanik bata ringan cellular lightweight concrete metode displacement control. JOM FTEKNIK, 6(1), 1-7.

Fajrin, J., Pathurahman, P., \& Pratama, L. G. (2016). Aplikasi Metode Analysis of Variance (Anova) Untuk Mengkaji Pengaruh Penambahan Silica Fume Terhadap Sifat Fisik Dan Mekanik Mortar. Jurnal Rekayasa Sipil (JRS-Unand), 12(1), 11. https://doi.org/10.25077/jrs.12.1.11-24.2016

Febrianto, E. (2016). Pengaruh Penambahan Silica Fume Pada Porous Concrete Block Terhadap Nilai Kuat Tekan Dan Permeabilitas. Jurnal Rekayasa Teknik Sipil (Rekats), 3(3), 1-8.

Maizir, H., Suryanita, R., \& Arditama, R. (2019). Study on performance of lightweight concrete bricks with a ratio of sand and cement composition. IOP Conference Series: Materials Science and Engineering, 615(1), 0-8. https://doi.org/10.1088/1757-899X/615/1/012105

Oktavianita, Y., Syamsudin, R., \& Zacoeb, A. (2014). Perbandingan Kuat Tekan dan Tegangan Regangan Bata Beton Ringan Dengan Penambahan Mineral Alami Zeolit Alam Bergradasi Tertentu Dengan dan Tanpa Perawatan Khusus. Jurnal Mahasiswa Jurusan Teknik Sipil, 1(3), $1-8$.

Sebayang, S. (2011). Tinjauan sifat-sifat mekanik beton alir mutu tinggi dengan silika fume sebagai bahan tambahan. Journal Rekayasa, 15(2), 131-138.

SNI 03-2847. (2019). Persyaratan Beton Struktural Untuk Bangunan Gedung Dan Penjelasan Sebagai Revisi Dari Standar Nasional Indonesia 2847 : 2013. Badan Standarisasi Nasional, 8, 1695.

Susilo, D. A. (2019). Efek Penggantian Sebagian Semen Dengan Silica Fume Terhadap Berat Jenis dan Kuat Tekan Beton Ringan. Efek Penggantian Sebagian Semen Dengan Silica Fume Terhadap Berat Jenis Dan Kuat Tekan Beton Ringan, 53(9), 1689-1699.

Tarru, R. O. (2017). Studi Penggunaan Silica Fume Sebagai Bahan Pengisi (Filler) Pada Campuran Beton. Jurnal Dynamic Saint, 3(1), 472-485. 